\title{
Judges, commerce and contract law
}

\author{
by John Gava
}

How should judges decide commercial cases, in particular, contract cases?

\section{CONTRACT IN ACTION}

This question received a powerful impetus with the publication of Stewart Macaulay's pioneering study in 1963 into the use of contract law in the market place. Macaulay looked at the contracting practices of businesses in Wisconsin and found that many entered into agreements that didn't satisfy the requirements of contract law and would not, therefore, be enforceable in the courts - and that the parties did not seem to care about this lack of enforceability. He also found that business people used a variety of non-legal methods, primarily trust and gossip, to ensure performance of their transactions. In addition he discovered that often contracts were written up for internal bureaucratic needs such as controlling sales people or acting as records for production purposes. Indeed, he found that many business people actively disliked the law and preferred to avoid its use wherever possible.

His work provoked an avalanche of studies, historical and contemporary, which showed that contract law seemed to be an unimportant and often unwanted aspect of commercial activities. Studies of medieval Jewish traders in Muslim North Africa and American traders in Mexican California showed flourishing trading networks that worked without the use of contract law and enforcement by the courts. In fact the New York Stock Exchange's first 50 years were marked by trading that was unenforceable in the courts, yet this did not faze the traders. Much of modern day commerce seems also to get on without recourse to contract law or to the courts. Studies ranging across diamond traders in New York, the US cotton and chemical industries as well as whole swathes of commerce associated with railway transportation, show business people either transacting without using enforceable contracts or deciding not to use the legal system at all and relying on of industry created private legal systems instead.

For some of these merchants contract law was not used because it was not available or it was ineffective. For others it was a matter of choice - contract law was not used because of its costs or because there were alternatives which worked better. Among these alternatives were trust, where traders felt comfortable enough with their fellow traders to not feel the necessity for a state enforced contract, and reputation, where traders were able to rely on gossip to police transactions and ensure performance. Some industries have gone further and created their own private legal systems to enforce their transactions.

Reading these numerous studies might tempt one to think that contract law is unnecessary and that business would get on well without it. But, of course, contract cases do reach the courts and businesses do pay expensive lawyers to draw up contracts. Since business people are not in the habit of subsidizing others' lifestyles, contract law must play some part in commerce. The difficulty is determining exactly what part it should play.

Of one thing we can be certain. Given the ubiquity of studies showing the non-use of law it seems that the common belief that transacting in the market takes place in the "shadow of the law" - that parties know that the law will be rarely invoked but that all transactions are completed in forms that could be argued in the courts- is simply not true. Rather, it appears that contract law is used in commerce but in special circumstances and for particular purposes. Instead of acting as a template for all transacting, contracts and contract law are used depending on the type of transaction and the type of industry involved.

Barak Richman has analysed the various forces operating in a transacting environment and suggested that transacting parties have three options in ensuring that transactions go ahead. According to Richman, the choice of option is a matter of cost and the type of industry in question. One option is vertical integration where a company, for example, buys a supplier to ensure that it gets the parts or resources necessary for its business to continue. This will not be considered further because this is a matter for corporate law and government regulation and not contract law. A second option, as was shown by Macaulay and others, is trust and reputation-based enforcement. Again, this will not be considered further as these mechanisms lie in the realm of industrial sociology and government 
industry policy. The remaining option is, of course, the law of contract. For some industries the law is either the only option available or it is used when it suits. So, while the law of contract might not be the most important mechanism for policing transactions it is used and requires analysis. It is this option that will be discussed here.

\section{WHEN IS CONTRACT USED?}

The first question then that arises from Macaulay's work is: when contract law is an option open to the transacting parties, under what circumstances is it likely to be used?

Hugh Collins has provided an interesting framework for analysing when commercial actors will and will not use the law of contract. He distinguishes three aspects of commercial transacting. The first, the economic deal, concerns a particular, discrete transaction. Use of the law here will depend on how important the transaction is. The second aspect of most transactions is the relationship between the parties. Most commercial actors deal in a series of transactions so that any particular transaction is worth less than the totality of potential transactions in the future. The third aspect is the contract itself which embodies the legal relationship between the parties. For Collins it is normally the business relationship that is the most important aspect of transacting, but in particular circumstances either the deal or the legally enforceable contract can assume first rank importance. For Collins while the law is potentially there to be used it is normally dormant, with the other aspects dominating the relationship between the parties. In other words, when parties enter into contracts they are not normally guiding their behaviour around a legal framework but, instead, are usually concentrating on building and maintaining a business relationship and ensuring that particular transactions are profitable. Contract law is an exceptional, but powerful, tool to be used when it is needed.

\section{RESPONSES - CONTEXTUALISM AND FORMALISM}

Having spelt out predictive tools about when and how contract law will be used leads to the second major issue facing legal scholars and judges. What should be the response of contract law to this third category of transacting where the law is there potentially to be used even if not used often? There are two major responses to this question, and they will be outlined below and their respective strengths and weaknesses discussed.

The first, which goes under various names such as antiformalism or dynamic market-individualism or contextualism, argues that the judges in deciding contract disputes and developing the law should give effect to the expectations, practices and desires of the business community. A contextualist law of contract would give primacy to standards such as good faith and unconscionability and look to business norms and practices to interpret contracts and to fill gaps where necessary. As Roger Brownsword describes it, such a law would be dynamic because it would be continually refined to give effect to changing business norms, expectations and behaviour.

The alternative response which, for ease of exposition we can call formalism, argues that since business uses law selectively, ie when the law suits its purposes, it would be counterproductive if the law were anything other than predictable. In other words, if the law is continually changing to match perceived notions of business needs or expectations (perceptions that at best can only be rough and ready approximations of these needs and expectations) the law would be unpredictable and not a useful tool for these businesspeople. Formalism eschews open-ended concepts such as good faith and relies on bright-line rules and strict limits on judicial discretion.

So, which style should judges employ in deciding commercial contract disputes? The problems facing a contextualist strategy seem daunting. First, this strategy depends on judges having sufficient information to make sure that both their decisions and the resulting developments of the law match precisely the needs of commerce. This means that accurate information about customary practices and expectations in particular industries as well as accurate information about particular transactions - all central to Collins's understanding of contextualist judging - have to be available to judges. But, of course, this is not going to be the case. Studies about particular industries are rare and liable to date very quickly. In the absence of timely studies will parties wait until a study is carried out, a process that might take a year or more? And who would pay for this study, the parties or the courts? In times of regular complaints that the courts are being starved for funds it is unlikely that governments would supply the money. Would the parties want to pay?

If we hold aside the question whether this sort of information exists in a readily usable form, one can also ask whether it would be likely that business people would want information about prices and short term and long term business strategies to become publicly available. Confidentiality lies at the heart of much business activity yet it is this sort of information upon which Collins bases his whole strategy.

Secondly, contextualism overestimates the capacity of judges and imposes on them a task which is beyond their abilities and training. Judges are practising lawyers, not practising market players. So, even if the market information that contextualism depends upon were available and inexpensive, there is no guarantee that the judges would be able to master this information to make decisions that conform to business practices and expectations. For example, in a study of the US Uniform Commercial Code, Richard Danzig has shown that where the Code requires judges to apply business custom in 
settling disputes what has actually happened is that judges have imposed their own values in the guise of applying business custom. In separate work both Roger Brownsword and Catherine Mitchell have shown that, in practice, a requirement for judges to apply reasonable expectations in deciding contract disputes inevitably morphs into an application of the judges' own values.

Thirdly, contextualism ignores the realities of power in the business environment. Any strategy which relies on litigation as a source for the development of law leaves itself open to being manipulated by repeat players. Repeat players are litigants who either because of greater resources or greater knowledge can and will use the courts strategically. As Marc Galanter showed many years ago repeat players are able to disproportionately influence the development of the law. Proponents of contextualism seem to ignore this dark side of litigation. Similarly, contextualists ignore the possibility that business norms reflect the values and customs of the more powerful. Would it be surprising that in an industry dominated by a few large corporations the ordinary customs surrounding exchange reflect the wishes and practices of these large market players? If this is the case, contextualism's strategy of converting market practices into law would only further cement the advantages held by these companies. In a similar way Collins's call for judges to give effect to the particular business relationship between two trading partners runs the risk that it would cement in law the imbalance of power embodied in the transaction between the parties.

But the most damning criticism of contextualism is that it will run against the interests of those it is aiming to help - market transactors. In very simple terms if, as Collins so persuasively argues, market participants use law selectively when it suits their purposes, predictability and certainty will be central to their requirements. A continually changing law which aims to track changing business needs, behaviour and expectations can only be unpredictable and, hence, unattractive to market players. All these problems suggest that contextualism will result in sub-optimal changes to the law. In general terms, then, it is unlikely that contextualism is a strategy that works to the benefit of market transactors.

In addition to these general concerns about the contextualist strategy, several scholars have suggested that contextualism raises specific problems for the market. Lisa Bernstein has argued that transactors value the possibility of waiving contractual rights at particular times in a particular business relationship while still wishing to reserve the right to enforce such rights in the case of future breaches (where, for example, the breach is seen as opportunistic rather than accidental or as being beyond the control of the other contracting party). If the judges misinterpreted the business relationship and accorded a conditional waiver the status of custom within that particular relationship the innocent party would be hesitant to waive accidental breaches in the future with this or any other transacting partner for fear that such a wavier would become legally entrenched. Bernstein's rigidity thesis has an intuitive appeal. If she is correct contextualism would make transacting less rather than more flexible and this would hardly add to business efficiency. Catherine Mitchell's analysis of entire contract clauses shows that even where parties embody in their contracts a desire to ensure that their agreement be treated formally a contextualist judge might set this wish aside and consider factors outside the written terms of the contract. Once a judge has acquired a taste for contextualist judging it is likely that even the parties' own request that their particular contract be treated in a formalist fashion might be ignored. Again, one has to ask how such a judicial response would aid market efficiency.

From one perspective the strengths of the formalist approach are the reverse of the weaknesses of contextualism. These weaknesses by themselves provide a strong argument in favour of formalism. But there are positive arguments as well.

First, as suggested above formalism supports party autonomy by giving the contracting parties maximum flexibility in deciding when and where to enforce their contractual rights. The predictability of a formal regime means that parties can plan around the law and have it in reserve if they choose to use it. The unpredictability of a contextualist regime reduces the parties' flexibility by introducing uncertainty about the ability of the parties to enforce those rights. In a nice irony, a formal and predictable law is more likely to be contextually aligned to the market and its practices.

Second, there is significant evidence that formalism is the preferred option of market players. Bernstein's study of private legal systems shows that these systems eschew contextualism in favour of bright line rules and formalist adjudication. When given the opportunity to design their own legal regimes, sophisticated traders rely on formalism as the preferred legal strategy. Recent studies by Eisenberg and Miller of publicly listed contracts containing choice of law and choice of forum clauses in the United States show that market participants tend to choose those states whose courts and law are formalist in nature and practice over those jurisdictions which are more contextualist. This shows that, given a choice, market traders seem to choose formal legal regimes over contextualist ones.

On purely intellectual terms, then, formalism seems a more convincing option than contextualism. But it is also probably true to say that, at least in the United Kingdom and Australia, contextualism is in the ascendant. Surprisingly, there is evidence of retreat from contextualism in the United States. The home of good faith has seen the attacks on this doctrine bear fruit as more and more judges accept the formalist arguments against a broad ranging doctrine of good faith. 


\section{COMMON LAW CONTRACT AND THE MARKET}

Viewed from a wider perspective, however, one can argue that despite their conflicting approaches to law, formalism and contextualism share some basic assumptions. Both see the underlying role of law as being to support and, if possible, enhance market transacting by shaping law to suit market needs. In furtherance of this goal both are willing to change the law to better suit market transacting. Of course, the amount and nature of change differs. As we have seen, contextualists such as Brownsword and Collins envisage a dynamic, ever changing law that continually adapts to suit changing business needs, behaviour and expectations. Formalism by its very nature eschews dynamic change but because of its commitment to the market, leading formalists have argued for one off adjustments to tidy up annoying or dysfunctional (from the market's perspective) rules. Scott and Schwartz have made such a proposal, listing a series of small but significant changes that would make contract law even more attractive to the market. Formalists owe no allegiance to the common law of contract but only to the best formalist regime that they can create.

Not only do both formalists and contextualists see the role of contract law as being an aid to market transacting, they also share an indifference to the common law of contract. Clearly contextualists who favour a dynamic contract law owing its dynamism to the market and its perceived needs cannot be said to have any fidelity to the common law. But formalists too base their preferred model of law, in their case predictable rules applied in a formalistic manner, on the needs of the market. In other words contextualism and formalism present an example of strategic congruence - seeing the law as a tool for the market - and tactical divergence - diametrically opposed views on how to achieve this goal. Neither displays any commitment to the common law and given their shared assumption that the role of contract law is to aid market transacting this should not be surprising.

This raises the third major issue that comes out of the responses to Macaulay's findings. Even if one accepts that formalism is more likely to suit the needs of the market should we understand contract law as primarily a tool to aid market transacting? I think not for three, interlocking reasons which I label as constitutional, historical and institutional.

The common law of contract is part and parcel of the common law which was developed in the United Kingdom and inherited and further developed in the United States and Australia, among other countries. The latter two have a written constitution but, of course, both constitutions presuppose and are reliant on the common law as a foundation of their respective constitutional structures. The common law is judge-made law and its development has always been distinctively legal. The common law has grown by judges developing the common law rules that they have inherited using what is commonly called legal reasoning. While there is justified debate about how insular this reasoning is and how much it is affected by instrumental concerns arising out of politics, economics and social forces and ideas, in the common law rules have an identifiable legal basis. If, however, the development of the common law of contract were to be purely driven by an instrumentalist desire to make the law reflect the practices, needs and expectations of the business community a fundamental constitutional barrier would be crossed. Instead of change and development in the law being driven by the legal reasoning of professional judges it would, instead, reflect the needs and desires of the market. I think that such a move would be illegitimate and unconstitutional.

The constitutional aspect of the law of contract relates mainly to legitimacy. Another way of looking at contract is historical. The common law of contract had a long gestation in the common law but on even the most conservative view it is over 400 years old. An institution of this heritage is worthy of respect on its own terms. Perhaps such an argument is too Burkean for modern tastes but surely such an institutional heritage merits caution when presented with a challenge, and contextualism most certainly provides a fundamental challenge to the historically developed law of contract. Longevity and tradition should not be overridden too easily.

Finally there is an institutional aspect to this question. Contextualism in essence amounts to sub-contracting development in the law of contract to the marketplace. Although the judges will be the formal agents of change, a truly dynamic contextualist law of contract will ultimately amount to the source of legal change being the needs, behaviour and expectations of the market, not the legal products of a process of professional legal reasoning. But, of course, if this change were to occur the same judges who would decide contract cases instrumentally would also be deciding cases in other areas of law. Could they quarantine contract from other areas or would there be irresistible pressure to replicate what was happening in contract in other areas of the law? For example, would tax cases be decided by interpreting tax legislation in light of the behaviour or desires of taxpayers or the taxation authorities (or a mixture of both)? Would criminal law be developed in line with the expectations of the general public, the police, criminals or politicians? It is difficult to believe that judges could be schizophrenic and it is much more likely that instrumentalism would ultimately come to dominate other areas of law as well.

Of course this discussion is premised on the notion that common law judging is an independent, professional form of legal reasoning and not instrumentally focussed on delivering particular social, economic or political outcomes. Or, in other words, that judging in the common law is legal rather than political. It is no secret that for 
many, perhaps most, legal scholars it is extremely unfashionable to see legal reasoning and judging as anything other than instrumental and many judges, especially in the United States, agree with this understanding of the judicial role. If this view is correct or becomes the majority view (which amounts to the same thing) this concern with the integrity and continued existence of traditional common law contract becomes irrelevant. If the common law is just another governmental or regulatory tool, the common belief of the formalists and contextualists makes perfect sense and the only real question remaining then is not the goal, which is common to both, but the tactics to be chosen, which of course is the bone of contention between the two groups.

\section{CONCLUSION}

Much contract law scholarship today is doctrinal, concentrating on the way in which judges develop and apply the plethora of rules and principles that make up the common law of contract. I think that this is an appropriate endeavour. But, given the evidence that contract law is not much used in the marketplace and given the intuitive attractiveness of the contextualist approach - if the law is not being used much let's make it more attractive to market players - doctrinal scholars cannot just keep doing what they do. They also need to justify what they do by showing that there are very good reasons, constitutional, historical and institutional, for continuing traditional black-letter, doctrinal scholarship. Otherwise they might find that no one, especially the judges, is listening any more.

\section{John Gava}

Reader, Adelaide Law School 